\title{
PENGEMBANGAN MODEL PEMBELAJARAN BERBASIS KARTU SOAL DENGAN PENDEKATAN KONSTRUTIVISTIK PADA MAHASISWA PGSD STKIP MELAWI
}

\author{
Fransisco Adam/Yuli Budhiarti/Samsul Bahri \\ Sekolah Tinggi Keguruan dan Ilmu Pendidikan (STKIP) Melawi \\ Kampus Wilayah Perbatasan Entikong \\ Email:adamtp84@gmail.com/yulibudhiarti22@ymail.com/samsulbahri804@gmail.com
}

\begin{abstract}
Development research is research that produces a new product, in the form of concepts, theories, models, methods, strategies, and media in a learning process. The product is expected to provide benefits both theoretically and practically in improving the quality of learning. This study aims to determine the effectiveness of the card-based learning model with constructivist approaches in improving learning outcomes and learning activeness. The study used an experimental method of one group pretest-posttest design with descriptive qualitative and quantitative narrative approaches. Procedural development model consisting of; potential and problems, data collection, product design, validation and revision, testing and final products. Data collection techniques and instruments used observation and test techniques with observation sheet instruments and question exercises (pretest-posttest). Analysis of qualitative and quantitative descriptive narrative data. The results of data analysis found $40 \%$ of students with a difference in learning outcomes after actions above 10 points, $46.66 \%$ difference in learning outcomes below 10 points, $6.66 \%$ stagnant, and $6.66 \%$ decreased. While the activeness of learning before the action is $33.33 \%$ and $66.66 \%$ after the action. This means that learning outcomes and activeness increase significantly from the previous condition. So it can be concluded that the card-based learning model with a constructivist approach can improve learning outcomes and student learning activeness.
\end{abstract}

\section{Keyword: Construcivistic Approach, Problem Card}

\section{PENDAHULUAN}

Belajar adalah suatu proses atau upaya yang dilakukan setiap individu untuk mendapatkan perubahan tingkah laku, baik dalam bentuk pengetahuan, keterampilan, sikap dan nilai positif sebagai suatu pengalaman dari berbagai materi yang telah dipelajari. Belajar dapat juga diartikan sebagai segala aktivita spsikis yang dilakukan oleh setiap individu sehingga tingkah lakunya berbeda antara sebelum dan sesudah belajar. Perubahan tingkah laku atau tanggapan karena adanya pengalaman baru, memiliki kepandaian/ilmu setelah belajar, dan aktivitas berlatih. Arti belajar adalah suatu proses perubahan kepribadian seseorang dimana perubahaan tersebut dalam bentuk peningkatan kualitas perilaku, seperti peningkatan pengetahuan, keterampilan, dayapikir, pemahaman, sikap, dan berbagai kemampuan lainnya.

Sementara pembelajaran adalah proses interaksi peserta didik dengan pendidik dan sumber belajar pada suatu lingkungan belajar yang meliputi guru dan siswa yang saling bertukar informasi. Menurut Wikipedia, pengertian pembelajaran merupakan bantuan yang diberikan pendidik agar dapat terjadi proses perolehan ilmu dan pengetahuan, penguasaan kemahiran dan tabiat, serta pembentukan sikap dan kepercayaan pada peserta didik. Dengan kata lain, pengertian 
pembelajaran adalah proses untuk membantu peserta didik agar dapat belajar dengan baik.

Pada prinsipnya pembelajaran dilakukan oleh dua orang pelaku dan terjadi dua arah antara pendidik dan peserta didik. Belajar adalah proses interaksi antara pendidik, sumber belajar, media, lingkungan yang kemudian menciptakan pengetahuan dan pengalaman belajar melalui melakukan, mengamati, dan menganalisis. Pembelajaran membutuhkan sebuah proses yang disadari yang cenderung bersifat permanen dan mengubah perilaku (Thobroni dan Mustofa, 2011: 19). Kamus Besar Bahasa Indonesia (dalam Thobroni dan Mustofa, 2011: 18) mendefinisikan kata pembelajaran berasal dari kata ajar yang berarti petunjuk yang diberikan kepada orang supaya diketahui atau dituruti. Jadi pembelajaran adalah upaya atau tindakan membuat orang lain belajar melalui proses dan interaksi dalam kegiatan belajar.

Model pembelajaran adalah suatu perencanaan atau suatu pola yang digunakan sebagai pedoman dalam merencanakan pembelajaran dikelas atau pembelajaran dalam toturial dan untuk menentukan perangkat-perangkat pembelajaran termasuk didalamnya. Jadi, model pembelajaran pada dasarnya merupakan bentuk pembelajaran yang tergambar dari awal sampai akhir yang disajikan secara khas oleh guru. Dengan kata lain, model pembelajaran merupakan bungkus atau bingkai dari penerapan suatu pendekatan, metode, dan teknik pembelajaran.

Dengan kata lain model juga dapat dipandang sebagai upaya dan untuk mengkonkritkan sebuah teori sekaligus juga merupakan sebuah analogi dan representasi dari variabel-variabel yang terdapat di dalam teori tersebut. Dengan demikian definisi tersebut dapat di katakan bahwa model merupakan suatu proses pola pikir dan komponen-komponen yang terdapat di dalamnya, yang direpresentasikan dalam bentuk grafis dan/atau naratif.

Menurut faham konstruktivis pengetahuan merupakan konstruksi (bentukan) dari orang yang mengenal sesuatu (skemata). Pengetahuan tidak bisa ditransfer dari guru kepada orang lain, karena setiap orang mempunyai skema sendiri tentang apa yang diketahuinya. Pembentukan pengetahuan merupakan proses kognitif di mana terjadi proses asimilasi dan akomodasi untuk mencapai suatu keseimbangan sehingga terbentuk suatu skema (jamak: skemata) yang baru. Seseorang yang belajar itu berarti membentuk pengertian atau pengetahuan secara aktif dan terus-menerus.

Kontruksi berarti bersifat membangun, dalam konteks filsafat pendidikan, Konstruktivisme adalah suatu upaya membangun tata susunan hidup yang berbudaya modern. Konstruktivisme merupakan landasan berfikir (filosofi) pembelajaran konstektual yaitu bahwa pengetahuan dibangun oleh manusia sedikit demi sedikit, yang hasilnya diperluas melalui konteks yang terbatas dan tidak sekonyongkonyong. Pengetahuan bukanlah seperangkat fakta-fakta, konsep, atau kaidah yang siap untuk diambil dan diingat. Manusia harus mengkontruksi pengetahuan itu dan memberi makna melalui pengalaman nyata.

Sedangkan menurut Tran Vui Konstruktivisme adalah suatu filsafat belajar yang dibangun atas anggapan bahwa dengan memfreksikan pengalaman-pengalaman sendiri. Sedangkan teori konstruktivisme adalah sebuah teori yang memberikan kebebasan terhadap manusia yang ingin belajar atau mencari kebutuhannya dengan kemampuan untuk menemukan keinginan atau kebutuhannya tersebut denga bantuan fasilitasi orang lain.

Model pembelajaran yang mendukung teori belajar konstruktivistik adalah model pembelajaran kooperatif. Menurut Slavin (dalam Rusman, 2014: 201) pembelajaran kooperatif menggalakkan siswa berinteraksi secara aktif dan positif dalam kelompok.Ini membolehkan pertukaran ide dan pemeriksaan ide sendiri dalam suasana yang tidak terancam, sesuai dengan falsafah konstruktivistik. Dalam teori konstruktivistik ini lebih mengutamakan pada pembelajaran siswa yang dihadapkan pada masalah-masalah kompleks untuk mencari solusinya, selanjutnya menemukan bagian-bagian yang 
lebih sederhana atau keterampilan yang diharapkan.

Toeri belajar konstruktivistik menurut Piaget (dalam Thobroni dan Mustofa, 2011: 111) mengungkapkan tiga dalil pokok dalam kaitannya dengan tahap perkembangan intelektual atau tahap perkembangan konstruktivistik kognitif atau tahap perkembangan mental sebagai berikut; (1) Perkembangan intelektual terjadi melalui tahap-tahap beruntun yang selalu terjadi dengan urutan yang sama. Setiap manusia akan mengalami urutan-urutan tersebut dan dengan urutan yang sama. (2) Tahap-tahap tersebut didefinisikan sebagai suatu cluster dari operasi mental (pengurutan, pengekalan, pengelompokan, pembuatan hipotesis dan penarikan kesimpulan) yang menunjukkan adanya tingkah laku intelektual. (3) Gerakan melalui tahap-tahap tersebut dilengkapi oleh keseimbangan (equilibration), proses pengembangan yang menguraikan interaksi antara pengalaman (asimilasi) dan struktur kognitif yang timbul (akomodasi).

Media pembelajaran memiliki posisi yang sangat penting dalam kegiatan pembelajaran. Memilih media pembelajaran yang tepat dapat memberikan stimulus kepada siswa agar siswa lebih termotivasi dalam belajar. Media pembelajaran merupakan alat perantara yang dapat membangun kerangka pemikiran siswa dalam memahami suatu objek yang dipelajari. Oleh karena itu media belajar hendaknya dibuat semenarik mungkin dan dapat menyampaikan pesan belajar kepada siswa. Oemar Hamalik (dalam Musfiqon, 2012: 27) mendefinisikan media sebagai teknik yang digunakan dalam rangka lebih mengefektifkan komunikasi antara guru dan murid dalam proses pendidikan dan pembelajaran di sekolah.

Media kartu soal adalah sejumlah kartu yang memiliki variasi warna yang didalamnya berisi pertanyaan atau penyataan dari materi/ submateri yang telah dipelajari dalam kegiatan pembelajaran. Media kartu soal terbuat dari kertas vanilla/buffalo yang dirancang sedemikian rupa untuk keperluan belajar. Pembelajaran menggunakan kartu soal dapat mengaktifkan siswa baik secara kelompok maupun individu karena proses pembelajaran menggunakan kartu soal ini melibatkan semua siswa yang ada. Proses pembelajaran ini dapat mendorong siswa untuk aktif dan kreatif karena siswa bertanggungjawab secara individu terhadap tugasnya masing-masing.

Media kartu soal termasuk dalam ketegori media visual. Azhar (2016:89) menyatakan media berbasis visual (image atau perumpamaan) memegang peran yang sangat penting dalam proses belajar. Media visual dapat memperlancar pemahaman (misalnya melalui elaborasi struktur dan organisasi) dan memperkuat ingatan. Selain itu media visual juga dapat meningkatkan daya ingat. Media pengajaran digunakan dalam rangka upaya peningkatan atau mempertinggi mutu proses kegiatan belajarmengajar. Media pengajaran hendaknya dipandang sebagai sumber belajar yang digunakan dalam usaha memecahkan masalah yang dihadapi dalam proses belajar-mengajar.

Beberapa fungsi media pembelajaran menurut Levie \& Lents (1982) mengemukakan empat fungsi media pembelajaran, khususnya media visual, yaitu; Pertama fungsi atensi media visual merupakan inti, yaitu menarik dan mengarahkan perhatian siswa untuk berkonsentrasi kepada isi pelajaran yang berkaitan dengan makna visual yang ditampilkan atau menyertai teks materi pelajaran. Kedua fungsi afektif media visual dapat terlihat dari tingkat kenikmatan siswa ketika belajar (atau membaca) teks yang bergambar. Ketiga fungsi kognitif media visual terlihat dari temuan-temuan penelitian yang mengungkapkan bahwa lambang visual atau gambar memperlancar pencapaian tujuan untuk memahami dan mengingat informasi atau pesan yang terkandung dalam gambar. Keempat fungsi kompensatoris media pembelajaran terlihat dari hasil penelitian bahwa media visual yang memberikan konteks untuk memahami teks membantu siswa yang lemah dalam membaca untuk mengorganisasikan informasi dalam teks dan mengingatnya kembali. 
Pembelajaran secara umum didefinisikan sebagai suatu proses yang menyatukan kognitif, emosional, lingkungan dan pengalaman untuk memperoleh, meningkatkan, atau membuat perubahan pengetahuan, membentuk keterampilan, nilai, dan mengubah sudut pandang seseorang. Belajar sebagai suatu proses berfokus pada apa yang terjadi ketika pembelajaan berlangsung.

Teori belajar konstruktivisme adalah suatu teori belajar yang menekankan kepada siswa bahwa "para siswa sebagai pembelajar tidak boleh menerima begitu saja pengetahuan yang mereka dapatkan, tetapi mereka secara aktif harus membangun pengetahuan secara individual." Teori ini berpandangan bahwa siswa yang berinteraksi dengan berbagai obyek dan peristiwa akan lebih mudah memperoleh dan memahami pola-pola terhadap obyek dan peristiwa tersebut. Dengan demikian siswa sesungguhnya mampu membangun konseptualitas dan pemecahan masalah mereka sendiri. Oleh karena itu kemandirian dan kemampuan berinisiatif dalam proses pembelajaran sangat didorong untuk dikembangkan.

Pendekatan konstruktivisme mempunyai beberapa konsep umum seperti https://id.wikipedia.org/wiki/Konstruktivism e; (1) Pelajar aktif membina pengetahuan berasaskan pengalaman yang sudah ada. (2) Dalam konteks pembelajaran, pelajar seharusnya mampu membina pengetahuan mereka secara mandiri. (3) Pentingnya membina pengetahuan secara aktif oleh pelajar sendiri melalui proses saling memengaruhi antara pembelajaran terdahulu dengan pembelajaran terbaru. (4) Unsur terpenting dalam teori ini ialah seseorang membina pengetahuan dirinya secara aktif dengan cara membandingkan informasi baru dengan pemahamannya yang sudah ada. (5) Ketidakseimbangan merupakan faktor motivasi pembelajaran yang utama. Faktor ini berlaku apabila seorang pelajar menyadari gagasan-gagasannya tidak konsisten atau sesuai dengan pengetahuan ilmiah. (6) Bahan pengajaran yang disediakan perlu mempunyai perkaitan dengan pengalaman pelajar untuk menarik minat pelajar.

Dalam pembelajaran konstruktivistik menggunakan kartu soal pada intinya siswa diarahkan untuk belajar secara terstruktur dan mandiri melalui proses personal maupun kelompok guna membangun ide-ide, pengetahuan, pemahaman, dan keterampilan. Ide, pengetahuan, pemahaman, dan keterampilan yang diperoleh dalam kegiatan belajar yang meliputi mengamati, menalar, menganalisis, pengumpulan data dan informasi tersebut kemudian menjadi pengetahuan baru bagi mereka.

Pentingnya pembelajaran diarahkan pada proses personal, tujuannya adalah untuk memberi kesempatan kepada siswa untuk membangun pengetahuannya dengan cara dan proses yang dilakukan secara individu. Pengetahuan yang diperoleh dari kegiatan belajar dapat berupa pengalaman, sikap, dan keterampilan.

\section{METODE PENELITIAN}

Penelitian ini adalah penelitian pengembangan dengan pendekatan kuantitatif dan kualitatif deskriptif. Sedangkan metode penelitian adalah metode eksperimen bentuk one group pretest-posttest design. Model pengembangan merupakan dasar untuk mengembangkan produk yang dihasilkan. Model pengembangan dapat berupa model prosedural, konseptual, dan model teoritik. Pada penelitian ini digunakan model prosedural yang bersifat deskriptif, menunjukan langkah-langkah yang harus diikuti untuk menghasilkan produk. Adapun langkah-langkah penelitian pengembangan Sugiyono (dalam Nusa Putra, 2015: 125) menjelaskan langkah-langkah $R \& D$ sebagai berikut: (1) Potensi dan Masalah, (2) Pengumpulan Data, (3) Desain Produk, (4) Validasi, dan Revisi, (5) Ujicoba, (6) ProdukAkhir.

Penelitian dilakukan dikampus STKIP Melawi Kampus Wilayah Perbatasan Entikong dengan subjek penelitian adalah mahasiswa PGSD semester ganjil (lima) sebanyak 15 orang dengan karakteristik 9 (sembilan) orang perempuan dan 6 (enam) 
orang laki-laki. Waktu penelitian dilaksanakan pada tanggal 7 dan 14 Oktober tahun 2019. Teknik pengumpulan merupakan langkah-langkah atau cara yang harus ditempuh dan diikuti dalam melaksanakan suatu penelitian. Langkah-langkah tersebut dilakukan untuk mendapatkan data yang diperlukan dalam penelitian.

Pada penelitian ini teknik untuk mengumpulkan data adalah melalui pengamatan/observasi awal sebagai dasar untuk mengembangkan produk. Selain itu dilakukan tes (pretest dan posttest) untuk mengetahui keefektipan produk yang dikembangkan. Sedangkan instrument pengumpulan data yang digunakan adalah soal essay sebanyak 5 butir. Soal digunakan untuk (pretest dan posttest).

Analisis data dilakukan dengan teknik analisis kuantitatif dan kualitatif deskriptif. Data yang dianalisis adalah data awal berupa temuan yang di dapat dari analisis kebutuhan, data rancangan produk, data validasi dan revisi, data ujicoba produk (hasil pretest dan posttest) pada mahasiswa PGSD STKIP Melawi Kampus Wilayah Perbatasan Entikong dan produk akhir.

\section{HASIL PENELITIAN PEMBAHASAN}

DAN

Hasil

Langkap-langkah Pembelajaran Berbasis

Kartu Soal a. Kegiatan Awal:

1.Membentuk kelompok

2. Menyampaikan tata cara/ prosedur dan informasi penting dalam pembelajaran berbasis kartu soal

b. Kegiatan inti:

1.Menyampaikan materi atau submateri yang akan dipelajari kepada masingmasing kelompok.

2.Memberikan waktu kurang lebih 45 menit kepada mahasiswa untuk berdiskusi.

3.Membagikan amplop yang berisi kartu soal. Setiap amplop berisi satu kartu soal dan diberi nomor.

4.Mengundi (mahasiswa memilih kartu warna yang dipegang dosen/ guru.) Kartu undian diberi nomor sesuai dengan nomor amplop dibagikan kepada mahasiswa.

5.Memperhatikan dan mengarahkan jalannya diskusi tanya jawab antar mahasiswa.

6. Memberikan skor kepada masingmasing kelompok.

c. Penutup:

1. Menyampaikan apresiasi dan penghargaan serta mengevaluasi hasil diskusi mahasiswa.

2. Melakukan refleksi

3. Evaluasi (Latihan soal essay)

4. Penutup

Tabel 1. Hasil Belajar Sebelum dan Sesudah Tindakan

\begin{tabular}{llccc}
\hline \multirow{2}{*}{ No } & \multicolumn{1}{c}{ Nama } & \multicolumn{2}{c}{ Hasil Belajar } & \multirow{2}{*}{ Selisih Poin } \\
\cline { 3 - 4 } & & Sebelum & Sesudah & \\
\hline 1. & Julia Fitri Nelia & 60 & 68 & 8 poin \\
\hline 2. & Hendrikus Hendi & 65 & 67 & 2 poin \\
\hline 3. & Vila Ester Handika Susila & 54 & 65 & 11 poin \\
\hline 4. & Oktavia Tiara Kenny. M. & 75 & 81 & 6 poin \\
\hline 5. & Reva Apilia Wanti & 75 & 78 & 3 poin \\
\hline 6. & Kornelia Adinda & 60 & 66 & 6 poin \\
\hline 7. & Yogi Septa Putra & 77 & 80 & 3 poin \\
\hline 8. & Martina Etika Etiana & 65 & 68 & 3 poin \\
\hline 9. & Martinus Wiro & 67 & 67 & - \\
\hline 10. & Riski Wiliam & 11 & 40 & 29 poin \\
\hline
\end{tabular}




\begin{tabular}{lllll}
\hline 11. & Yuni Sapitri & 47 & 67 & 20 poin \\
\hline 12. & Yulius Tobias Golik & 42 & 37 & -5 poin \\
\hline 13. & Nopi Susanti & 37 & 56 & 19 poin \\
\hline 14. & Mida & 50 & 63 & 13 poin \\
\hline 15. & Teodorus Suhermus & 10 & 41 & 31 poin \\
\hline
\end{tabular}

Tabel 1. adalah perolehan belajar mahasiswa yang diukur sebelum dan sesudah tindakan. Data diatas menunjukan bahwa terdapat perbedaan (selisih) hasil belajar mahasiswa dari sebelum dan sesudah tindakan. Data tersebut menunjukan bahwa model pembelajaran yang dilaksanakan sebelumnya tidak memberikan banyak dampak kepada mahasiswa, hal tersebut dapat dilihat pada data perbandingan yang terdapat pada tabel diatas, dimana hasil belajar mahasiswa sesudah tindakan cenderung mengalami peningkatan walaupun terdapat dua orang mengalami stagnan dan penurunan namun relatif kecil. Artinya keberhasilan pengembangan model pembelajaran berbasis kartu soal dengan pendekatan konstruktivistik dapat dinyatakan memberikan pengaruh yang cukup bagi mahasiswa.

Tabel 2. Keaktifan Belajar Sebelum dan Sesudah Tindakan

\begin{tabular}{llcccc}
\hline \multirow{2}{*}{ No } & \multirow{2}{*}{ Nama } & \multicolumn{4}{c}{ Keaktifan } \\
\cline { 3 - 6 } & & \multicolumn{2}{c}{ Sebelum } & \multicolumn{3}{c}{ Sesudah } \\
\cline { 3 - 6 } & & Skor & Skala & Skor & Skala \\
\hline 1. & Julia Fitri Nelia & 22 & 2.4 & 27 & 3.0 \\
\hline 2. & Hendrikus Hendi & 20 & 2.2 & 27 & 3.0 \\
\hline 3. & Vila Ester Handika Susila & 15 & 1.7 & 27 & 3.0 \\
\hline 4. & Oktavia Tiara Kenny. M. & 19 & 2.1 & 27 & 3.0 \\
\hline 5. & Reva Apilia Wanti & 16 & 1.8 & 25 & 2.8 \\
\hline 6. & Kornelia Adinda & 19 & 2.1 & 27 & 3.0 \\
\hline 7. & Yogi Septa Putra & 21 & 2.3 & 27 & 3.0 \\
\hline 8. & Martina Etika Etiana & 12 & 1.3 & 27 & 3.0 \\
\hline 9. & Martinus Wiro & 18 & 2.0 & 27 & 3.0 \\
\hline 10. & Riski Wiliam & 11 & 1.2 & 22 & 2.4 \\
\hline 11. & Yuni Sapitri & 11 & 1.2 & 26 & 2.9 \\
\hline 12. & Yulius Tobias Golik & 10 & 1.1 & 21 & 2.3 \\
\hline 13. & Nopi Susanti & 12 & 1.3 & 27 & 3.0 \\
\hline 14. & Mida & 11 & 1.2 & 23 & 2.6 \\
\hline 15. & Teodorus Suhermus & 14 & 1.6 & 27 & 3.0 \\
\hline
\end{tabular}

Tabel 2. data diatas adalah data hasil observasi keaktifan mahasiswa selama proses belajar. Dari data tersebut dapat diketahui skala tertinggi keaktifan sebelum tindakan hanya mencapai 2.4 dan hanya satu orang mahasiswa dari lima belas populasi. Sementara jika dibandingkan dengan data keaktifan sesudah tindakan mengalami peningkatan yang sangat signifikan walaupun masih ada mahasiswa yang justru keaktifannya turun bahkan stagnan, namun peningkat yang terjadi tetap memberikan pengaruh positif bagi mahasiswa dalam kegiatan pembelajaran. Data pengamatan sesudah tindakan diketahui dari jumlah populasi tersebut nilai terendah berada pada 
skala 2.3 dan tertinggi berada pada nilai maksimal yakni 3.0. Sementara data sebelum tindakan nilai terendah berada pada skala 1.1 dan tertinggi pada skala 2.4. Artinya dari paparan data diatas diketahui bahwa model yang dikembangkan dapat memberikan pengaruh yang sangat berarti bagi peningkatan pemahaman, pengetahuan, dan aktivitas mahasiswa dalam kegiatan pembelajaran.

\section{Pembahasan}

Model pembelajaran didefinisikan sebagai suatu prosedur yang telah dibuat secara sistematis dengan tujuan agar dalam mengorganisasi pengalaman belajar lebih terarah sehingga dapat mencapai tujuan pembelajaran yang ingin dicapai. model pembelajaran juga diartikan sebagai suatu pendekatan yang digunakan dalam dunia belajar.

Permendikbud No.103 Tahun 2014 tentang Pembelajaran pada Pendidikan Dasar dan Pendidikan Menengah, Pasal 2. Menyatakan model pembelajaran adalah kerangka konseptual dan operasional pembelajaran yang memiliki nama, ciri, urutan logis, pengaturan, dan budaya. Model pembelajaran adalah kerangka konseptual yang menggambarkan prosedur sistematis dalam mengorganisasikan pengalaman belajar peserta didik untuk mencapai tujuan belajar tertentu dan berfungsi sebagai pedoman dalam merencanakan dan melaksanakan aktivitas belajar mengajar (Syaiful Sagala).

Secara umum, model pembelajaran adalah cara atau teknik penyajian sistematis yang digunakan oleh guru dalam mengorganisasikan pengalaman proses pembelajaran agar tercapai tujuan dari sebuah pembelajaran. Sementara teori belajar konstruktivistik didefinisikan sebagai pembelajaran yang bersifat generatif, yaitu tindakan mencipta sesuatu makna dari apa yang dipelajari.

Teori ini menekankan bagaimana peserta didik membina pengetahuan secara aktif melalui kegiatan pembelajaran. Menurut teori ini, satu prinsip yang mendasar adalah guru tidak hanya memberikan pengetahuan kepada siswa, namun siswa juga harus berperan aktif membangun sendiri pengetahuan di dalam memorinya. Konstruktivisme pembelajaran ialah desain pembelajaran yang menekankan kemampuan peserta didik dalam mengkonstruksi pengatahuannya sendiri, bukan serta merta pendidik yang selalu menjadi senter penerang di kala gelap melanda. (Aunurrahman, 2009).

Namun disinilah setiap peserta didik secara individual harus dan layak memiliki kemampuan untuk memperdayakan fungsifungsi psikis dan mental yang dimilikinya yaitu kemampuan mengingat dan mengungkapkan kembali pengalaman yang lalu, membandingkan dan mengambil sebuah keputusan dan kemampuan yang lebih menyukai satu dari yang lainnya. Senada dengan Aunurrahman, Donald R. (2006) mengemukana bahwa "Constructivism is a way of teaching and learning that intends to maximize student understanding". Maksudnya, kontruktivisme adalah suatu cara dalam pengajaran dan pembelajaran yang tujuannya adalah untuk memaksimalkan pemahaman siswa.

Pada hakikatnya pembelajaran konstruktivistik memandang subyek aktif menciptakan struktur-struktur kognitif dalam interaksinya dengan lingkungan. Dengan bantuan struktur kognitifnya ini, subyek menyusun pengertian realitasnya. Interaksi kognitif akan terjadi sejauh realitas tersebut disusun melalui struktur kognitif yang diciptakan oleh subyek itu sendiri. Struktur kognitif senantiasa harus diubah dan disesuaikan berdasarkan tuntutan lingkungan dan organisme yang sedang berubah. Proses penyesuaian diri terjadi secara terus menerus melalui proses rekonstruksi.

Pembelajaran berbasis kartu soal dengan pendekatan konstruktivistik merupakan pendekatan pembelajaran yang menekankan pada produktivitas belajar mahasiswa dalam mengembangkan ide dan gagasan, menciptakan struktur kognitif, membangun konsep, serta mengeplorasikan pengetahuan dan pemahaman secara kritis. Oleh sebab itu, pembelajaran dirancang sedemikian rupa agar mahasiswa dapat memaksimalkan potensi 
yang dimiliki melalui kegiatan pembelajaran yang kreatif, interaktif, dan produktif. Pembelajaran yang kreatif, interaktif, dan produktif dimana mahasiswa berperan aktif menemukan ide dan gagasan dalam memecahkan masalah belajar.

Pembelajaran ini dikembangkan untuk membiasakan mahasiswa berpikir konsep dan kritis melalui kajian, analisis, pengamatan, mengingat, dan mengekplorasikan pemahaman dan pengetahuan secara terstruktur dan logis. Pembelajaran berbasis kartu soal dengan pendekatan konstruktivistik dilaksanakan dengan belajar berkelompok. Kelompok dibagi sesuai dengan jumlah mahasiswa, namun dalam setiap kelompok maksimal 4-5 anggota. Hal ini dilakukan agar kegiatan diskusi dan Tanya jawab atau penyampaian ide dan gagasan secara kritis bisa lebih maksimal.

Tujuan pengembangan pembelajaran berbasis kartu soal dengan pendekatan konstruktivistik adalah untuk menciptakan suasana belajar yang interaktif dan produktif. Pembelajaran yang interaktif dan produktif dapat menemukan ide dan gagasan serta pengetahuan baru. Penemuan ide dan gagasan serta pengetahuan baru dapat diperoleh melalui konsep berpikir kritis, analitik, komperehensif, dan terstruktur terhadap suatu masalah. Konsep berpikir kritis dan analitik dibangun melalui cara belajar mandiri dengan mengkaji dan menganalisis suatu masalah atau kasus yang nyata guna mengetahui hubungan sebab akibat (kausalitas) dari suatu masalah yang dikaji untuk kemudian menarik kesimpulan. Dengan demikain, maka terbangunlah pemahaman dan pengetahuan yang terstruktur pada diri mahasiswa.

Efektivitas merupakan suatu kondisi yang menunjukkan seberapa jauh suatu target yang sudah diraih oleh manajemen seperti kualitas, kuantitas, dan waktu. Yang mana target tersebut telah ditetapkan terlebih dahulu. Dalam Kamus Besar Bahasa Indonesia (KBBI), kata efektif mempunyai arti efek, pengaruh, akibat atau dapat membawa hasil. Jadi, efektivitas adalah keaktifan, daya guna, adanya kesesuaian dalam suatu kegiatan orang yang melaksanakan tugas dengan sasaran yang dituju. Efektivitas pada dasarnya menunjukkan pada taraf tercapainya hasil, sering atau senantiasa dikaitkan dengan pengertian efisien, meskipun sebenarnya ada perbedaan diantara keduanya. Efektivitas menekankan pada hasil yang dicapai, sedangkan efisiensi lebih melihat pada bagaiman cara mencapai hasil yang dicapai itu dengan membandingkan antara input dan outputnya (Siagaan, 2001).

Senada dengan Siagian, Schemerhon John menyatakan efektivitas adalah pencapaian target keluaran (output) yang akan diukur dengan cara membandingkan output anggaran atau OA (seharusnya) dengan output realisasi atau OS sesungguhnya). Jika OA > OS maka akan disebut dengan efektif. Oleh sebab itu, untuk mencapai suatu target yang dinginkan dari suatu rencana, diperlukan konsep yang dirancang secara sistematis dan logis.

Pembelajaran yang dikembangkan mesti dilakukan melalui tahapan-tahapan yang sistematis dan logis. Tahapan-tahapan tersebut dilakukan melalui tahap desain, validasi, ujicoba sampai pada produk akhir dari pengembangan tersebut. Pada tahap awal dilakukan rancangan yang akan dikembangkan, rancangan dapat dalam bentuk kerangka konsep, model, metode, ataupun strategi. Dalam pengemabangan ini rancangan awal dalam bentuk model pembelajaran berbasis kartu soal dengan pendekatan konstruktivistik dengan kerangka atau konsep pembelajaran disusun atau dirancang secara prosedural sistematis melalui langkahlangkah pembelajaran menggunakan kartu soal.

Selain itu, rancangan pembelajaran yang dirancang perlu divalidasi oleh ahli dalam hal ini adalah orang yang berkompeten dibidang itu. Tujuan daripada validasi adalah untuk mengetahui dan memastikan bahwa model tersebut benar-benar valid dan layak untuk digunakan. Setelah tahap rancangan dan validasi selesai selanjutnya model tersebut dilakukan ujicoba kelompok kecil maupun kelompok besar. Hal tersebut dilakukan 
bertujuan untuk mengetahui efektivitas atau keberhasilan dari model tersebut.

Pada pengembangan ini subjek ujicoba dilakukan pada mahasiswa PGSD semester satu yang berjumlah lima belas orang. Ujicoba produk dilakukan dengan memperhatikan dua aspek output yang diharapkan, yakni hasil belajar, dan keaktifan belajar. Pada aspek pertama dilakukan dengan melakukan tes pemahaman dan pengetahuan mahasiswa terhadap materi yang telah dipelajari melalui latihan soal essay sebanyak lima butir.

Aspek berikutnya yakni efektivitas (keaktifan) dilakukan dengan cara pengamatan selama proses pembelajaran. Pengamatan dilakukan dengan mengamati paling tidak sembilan aspek yang telah disusun. Kesembilan aspek tersebut antara lain adalah; (a) Bertanya kepada guru/dosen/teman, (b). Menjawab pertanyaan guru/ dosen/teman, (c) Diskusi dengan kelompok, (d) Bekerjasama dalam kelompok, (e) Mengamati kegiatan presentasi/penjelasan, (f) Mendengarkan sajian presentasi/ penjelasan, (h) Mengemukakan pendapat, (i) Percaya diri dalam kegiatan pembelajaran, (j) Mendengarkan penjelasan/informasi.

Sementara latihan soal essay dilakukan untuk melihat kemampuan mahasiswa menjawab pertanyaan/penyataan dengan tepat dan benar. Kemampuan menjawab soal dengan tepat dilihat dari kemampuan mahasiswa mengeksplorasikan gagasannya secara kritis dan benar. Untuk mengetahui hasil ujicoba produk yang dikembangkan pada pembelajaran ini dapat disajikan melalui hasil belajar dan keaktifan mahasiswa pada grafik berikut:

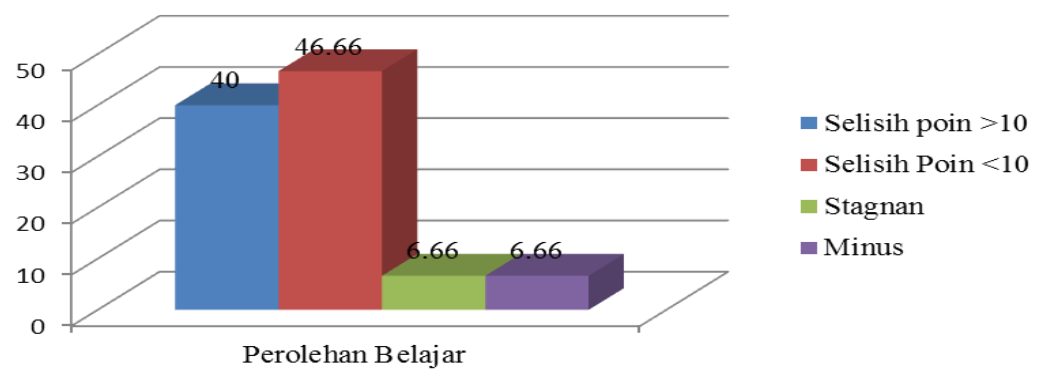

\section{Gambar 1. Grafik Selisih Perolehan Belajar Sesudah Tindakan}

Data perolehan belajar pada grafik diatas menunjukan besaran selisih poin diatas sepuluh poin dan besaran selisih dibawah sepuluh poin. Hal ini menunjukan bahwa produk yang dikembangkan menunjukan dampak positif terhadap hasil belajar. Data tersebut bila dibandingkan jumlah selisih poin dari keadaan yang stagnan dan kurang, maka nilai atau jumlah selisih poin lebih tinggi atau lebih besar dibanding jumlah stagnan dan minus. Dari paparan data tersebut, maka model pembelajaran berbasis kartu soal dengan pendekatan konstruktivistik dapat memberi pengaruh yang signifikan terhadap hasil belajar. Dengan demikian pembelajaran berbasis kartu soal dengan pendekatan konstruktivistik cukup efektif dalam meningkatkan hasil belajar.

Hasil belajar yang dimaksud disini bukan sekedar mahasiswa dapat mencapai angka maksimal, melain bagaimana mahasiswa dapat menjawab pertanyaan atau pernyataan dengan uraian yang kritis, tepat dan terukur. Oleh sebab itu proses pembelajaran menjadi penting dan menentukan perkembangan pola berpikir mahasiswa dalam mempelajari, mengkaji, dan menganalisis suatu masalah yang dipelajari. Kemampuan berpikir analitik seperti ini yang perlu dikembangkan oleh mahasiswa bukan kemampuan berpikir satu arah yang hanya untuk menemukan satu jawaban yang belum tentu tepat dan benar. 


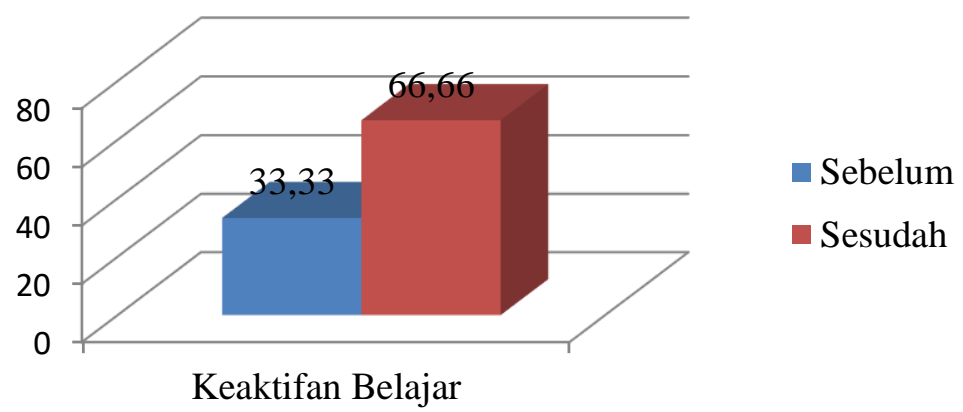

Gambar 2. Grafik Keaktifan Belajar

Selain dapat mempengaruhi hasil belajar seperti yang telah dipaparkan pada grafik perolehan hasil belajar diatas, dimana jumlah mahasiswa yang aktif sebelum tindakan sebenyak lima orang atau $33.33 \%$ dari lima belas orang subjek, sedangkan hasil penelitian menunjukkan terdapat peningkatan sebesar $66.66 \%$ dari sebelumnya. Arati pembelajaran berbasis kartu soal dengan pendekatan konstruktivistik sangat berpengaruh terhadap keaktifan belajar. Angka yang tersaji pada grafik tersebut menunjukan adanya perbedaan antar nilai keaktifan belajar mahasiswa sebelum dan sesudah tindakan. Artinya model pembelajaran tersebut dapat mempengaruhi dua aspek tersebut. Kedua aspek tersebut saling berkaitan sehingga apabila aktivitas belajar baik, maka akan berdampak pada hasil belajar demikian sebaliknya. Namun kedua hal tersebut tidak dapat tercapai apabila model atau metode pembelajaran tidak menjangkau kedua aspek tersebut.

Pembelajaran akan lebih efektif bilamana mahasiswa dapat memanfaatkan seluruh komponen kompetensi yang dimilikinya, baik itu kognitif, afektif, dan psikomotorik. Komponen kompetensi itu harus diberdayakan oleh mahasiswa untuk menemukan pengetahuan dan pemahaman secara kritis dan terstruktur. Kegiatan belajar yang inovatif, interaktif, dan produktif dapat memberikan pengalaman belajar yang bermanfaat bagi mahasiswa. Oleh sebab itu peran guru atau dosen sebagai roh dalam pembelajaran harus mampu merancang dan menciptakan suasana belajar yang menarik bagi mahasiswa. Belajar mesti dirancang sedemikian rupa agar tujuan pembelajaran dapat tercapai.

\section{SIMPULAN DAN SARAN Simpulan}

Pembelajaran berbasis kartu soal dengan pendekatan konstruktivistik yang menjadi fokus pada penelitian ini telah dilaksanakan melalui tahapan-tahapan sebagaimana telah dipaparkan pada bab sebelumnya. Dari hasil penelitian yang telah dilaksanakan, maka dapat ditarik kesimpulan bahwa pembelajaran berbasis kartu soal dengan pendekatan konstruktivistik pada mahasiswa cukup efektif dalam mengembangkan kemampuan berpikir kritis dan terstruktur serta meningkatkan hasil belajar dan keaktifan belajar. Hasil analisis data diketahui sebanyak 40\% mahasiswa dengan selisih nilai hasil belajar setelah tindakan diatas 10 poin, $46.66 \%$ selisih nilai hasil belajar dibawah 10 poin, $6.66 \%$ stagnan, dan $6.66 \%$ menurun. Sementara keaktifan belajar sebelum tindakan sebesar $37.3 \%$ dan $43.3 \%$ setelah tindakan. Artinya hasil belajar dan keaktifan meningkat signifikan dari kondisi sebelumnya.

\section{Saran}

Berdasarkan hasil penelitian dan kesimpulan diatas, tentu penelitian ini masih terdapat banyak kekuranngan baik dari sisi pengetahuan maupun luaran yang dihasilkan pada penelitian, maka saran yang dapat peneliti sampaikan baik bagi peneliti maupun pembaca lain adalah sebagai berikut: (1) 
Proses pembelajaran hendaknya dirancang dengan memperhatikan kebutuhan dan karakteristik pebelajar agar kegiatan belajar lebih interaktif dan produktif serta mencapai bersama siswa; (3) Kegiatan pembelajaran seyogyanya dapat melibatkan, mengembangkan, dan memberdayakan seluruh komponen kompetensi yang dimiliki siswa; (4) Iklim belajar yang kondusif dan menyenangkan dapat menciptakan suasana belajar yang menarik dan bermakna; (6) Guru atau dosen harus senantiasa terus menerus mengembangkan pengetahuan dan kemampuan melalui inovasi-inovasi yang berbasis literasi dalam mengembangkan konsep, model, metode, dan strategi dalam pembelajaran.

\section{DAFTAR PUSTAKA}

Arsyad. 2016. Media Pembelajaran. Jakarta: PT. Raja Grafindo Persada.

Aunurrahman. 2009. Belajar dan Pembelajaran. Bandung: Alfabeta.

Donald R, et.al. (2006). The act of teaching, Fourth Edition. New York: McGrawHill. tujuan yang diharapkan; (2) Pembelajaran mesti terus diperbarui melalui inovasi-inovasi yang dilakukan baik oleh guru maupun guru

Isjoni. 2007. Cooperative Learning. Banduung: Alfabeta.

Musfiqon. 2012. Pengembangan Media dan Sumber Pembelajaran. Jakarta: Prestasi Pustaka Publisher.

Nurhadi, dkk. 2003. Pembelajaran Kontekstual (Cooperative Learnig di Ruang-ruang Kelas). Jakarta; Gramedia Widiasarana. 2004. Pembelajaran kontekstual dan Penerapan dalam KBK. Malang: Universitas Negeri Malang

Putra Nusa. 2015. Reaserch dan Development. Jakarta: PT. Raja Grafindo Persada.

Rusman. 2014. Model-Model Pembelajaran. Jakarta: PT. Raja Grafindo Persada.

Thobroni dan Mustofa. 2011. Belajar dan Pembelajaran. Jogjakarta: Ar-Ruzz Media. 